\title{
12. Hungary
}

\section{Anna Forgács}

\section{INTRODUCTION}

Direct-democratic instruments were introduced in Hungary in 1989, as part of the process of democratic transition, ${ }^{1}$ when they were put to a test at once by the so-called 'four-yes' referendum about demolishing the remains of the communist party structure and the election of the President. Even though direct democracy has a short history in Hungary, already the second legal regime is in force, as after the adoption of the new Constitution in 2011 (Fundamental Law) $)^{2}$ a new act on referendums (Referendum Act) ${ }^{3}$ was also created.

The constitutional system builds on representative democracy as the main pillar of the exercise of popular sovereignty. From the early days of Hungarian democracy, direct democracy has been regarded as an exceptional form of popular sovereignty, which is exercised seldom but on such occasions it presides over representative democracy. ${ }^{4}$ This exceptionality also shows in numbers: Hungarian voters have been asked to answer 13 referendum questions on seven occasions ${ }^{5}$ since 1989 , even though the number of referendums initiated annually is well in the hundreds since 2006-2007. ${ }^{6}$

1 They were first introduced by the Act XVII of 1989 even before the major democratic constitutional reform. For a summary of the historical evolution of direct democracy in Hungary (including current trends) see László Komáromi, 'Milestones in the History of Direct Democracy in Hungary’ (2013) 9(4) Iustum Aequum Salutare 41.

2 The Fundamental Law of Hungary was adopted on 25 April 2011 and entered into force on 1 January 2012 http://njt.hu/translated/doc/TheFundamentalLawofHungary _20190101_FIN.pdf, accessed 1 April 2020.

Act $\bar{C}$ CXXXVIII of 2013 on Initiating Referendums, the European Citizens' Initiative and Referendum Procedure https://www.valasztas.hu/web/national-election -office/act-ccxxxviii-of-2013-on-initiating-referendums-the-european-citizens -initiative-and-referendum-procedure, accessed 1 April 2020.

$4 \quad$ 52/1997 (X. 14.) Constitutional Court (CC) decision, 2/1993 (I. 22.) CC decision.

5 See http://c2d.ch/country/HU, accessed 1 April 2020.

6 For the reasons behind the rise of initiatives see: Zoltán Tibor Pállinger, 'Potentials of Direct Democracy in an Extremely Majoritarian System: The Case of Hungary' (2016) Andrássy Working Papers zur Demokratieforschung 1/2016, 
The National Election Office has provided statistical overviews since 2002, ${ }^{7}$ but in the 1990s the number of initiatives per year did not reach $50 .^{8}$ The available statistical information shows that between May 2002 and December 2019 the number of questions submitted for authorization was 2,153 at national level. Out of these 2,153 questions, the election authorities validated only 186 questions, which is 8.6 per cent of all questions.

One of the main reasons behind this huge contrast between the number of referendums initiated and actually taking place lies in the elaborate system of substantive and formal limits imposed on direct-democratic initiatives, coupled with a rigorous administrative and judicial review procedure. The Fundamental Law explicitly prohibits referendums in ten subject matters, while the Referendum Act adds the formal limit of clarity to the restrictions, which is the most common ground for refusing validation.

\section{DIRECT-DEMOCRATIC INSTRUMENTS}

Article 8 of the Fundamental Law contains the main provisions regarding nationwide referendums. A referendum can be initiated by citizens or the executive (President or Government) and it can be proactive or rejective (abrogative). Although this is not specified in the legal provisions, ${ }^{9}$ the consistent practice of the election bodies has been to authorize both questions that are generally phrased and those proposing to amend or abrogate specific legal provisions. $^{10}$

Most of the initiatives are submitted by private individuals or political parties, with the recent exception of the 2016 quota-referendum, ${ }^{11}$ which was

17 https://www.andrassyuni.eu/pubfile/de-209-1-2016-wp-1-def.pdf, accessed 1 April 2020.

7 See https://www.valasztas.hu/documents/20182/305738/Statisztik\%C3\%A1k+ az+elb $\% \mathrm{C} 3 \% \mathrm{ADr} \% \mathrm{C} 3 \% \mathrm{~A} 11 \mathrm{t}+\mathrm{n} \% \mathrm{C} 3 \% \mathrm{~A} 9$ pszavaz $\% \mathrm{C} 3 \% \mathrm{~A} 1$ si + kezdem $\% \mathrm{C} 3 \% \mathrm{~A} 9$ nyez \%C3\%A9sekr\%C5\%911.pdf/a0655454-ecd7-412f-ab08-8a23dc419f5e, accessed 1 April 2020.

8 Gabriella Antalicz, 'Magyarországi Országos Népszavazási Kezdeményezések Statisztikai Elemzése’ (2019) 15(1) Iustum Aequum Salutare 171, 172.

9 The old Constitution contained a provision about confirmatory referendums in Art. 26(1), which is not part of the current system. See 64/2009 (VI. 18.) CC decision.

10 Most recently the $15 / 2017$ (VI. 30.) CC decision clarified that the Fundamental Law does not limit the aim or form of the referendum initiative. It can be aimed to amend, abrogate or create a legislative act or other legislative decision; the question can be the summary of its content, an actual legislative provision or a reference to a legal act or proposed legal act. See 15/2017 (VI. 30.) CC decision, paragraph 32.

11 Andrew MacDowall, 'Voters back Viktor Orbán's rejection of EU migrant quotas' Politico (Brussels, 2 October 2016) https://www.politico.eu/article/hungary -referendum-eu-migration-viktor-orban/, accessed 1 April 2020. 
a plebiscite initiated by the Government. The only other referendum initiated by state actors was the referendum on the accession to NATO, while the referendum on the accession to the EU was specifically mandated by law. In case a referendum is initiated by 200,000 citizens, it is obligatory to call the referendum, while in case a referendum is proposed by the President, the Government or 100,000 citizens, the parliament may order a referendum but is not obliged to do so. ${ }^{12}$ In the Hungarian jurisprudence this distinction is referred to as that between 'mandatory' and 'facultative' referendums.

The legal provisions governing referendums - including limits and procedures - are the same for all direct-democratic instruments regardless of whether they are initiated by citizens or state institutions. After the referendum question is formulated, it has to be submitted to the National Election Commission, which reviews its compliance with formal and substantive limits. A legal remedy against the validation decision is provided by the supreme court (Curia), against which a constitutional complaint procedure may be initiated at the Constitutional Court. After the validation, citizens have 120 days to collect signatures. In all cases, the simple majority of the members of parliament (National Assembly) makes the decision on calling the referendum, and the President sets its date. The same quorum applies for all types of direct-democratic instruments: the majority of people with voting rights have to participate, with the majority of participants approving the referendum in order for it to be valid. If the quorum is met, the referendum results are binding and must be implemented. ${ }^{13}$

The citizen-initiated referendum is the only type of referendum that exists both at local and national level. Law-initiated referendums and legislature-initiated referendums are only present at local level, ${ }^{14}$ while agenda initiatives have been abolished in the new constitutional system.

This chapter will analyse only national-level referendums in further detail. Even though there have been some interesting local cases in Budapest, ${ }^{15}$ the

12 The Constitutional Court analysed the relationship between the two types in 52/1997 (X. 14.) CC decision, English summary http://www.codices.coe.int/NXT/ gateway.dll/CODICES/precis/eng/eur/hun/hun-1997-3-009?fn=document-frameset $. h t m \$ f=$ templates $\$ 3.0$, accessed 1 April 2020.

13 See Art. 8 Fundamental Law.

14 Art. 98-105 Act CLXXXIX of 2011 on the Local Self-Governments of Hungary. The only exception is the referendum regarding the accession to the EU, where Art. 79 of the old Constitution mandated that a referendum has to be held on this specific issue and also that the referendum has to take place on 12 April 2003.

15 In recent years there have been a number of initiatives related to the new Museum district to be built in City park and related to Budapest applying for the organization of the Summer Olympics. See: Knk.VII.37.644/2017/2, Knk.VII.37.306/2017/2, Knk.IV.37.298/2017/4, Knk.IV.38.143/2015/6. 
most relevant referendum experience comes from national referendums and initiatives. The so-called 'national consultation' is also excluded from the analysis. It is a non-binding public questionnaire circulated by the government on various topics; however, it does not have any constitutional or legal basis. It is an ad hoc political tool which could not be considered a genuine instrument of direct democracy. ${ }^{16}$

\section{SUBSTANTIVE LEGAL LIMITS ON REFERENDUMS}

Article 8(2)-(3) of the Fundamental Law contains the substantive limits of referendums, which consist of the positive scope of referendums and the prohibited subjects:

National referendums may be held about any matter falling within the functions and powers of the National Assembly, while no national referendum may be held on:

(a) any matter aimed at the amendment of the Fundamental Law;

(b) the content of the Acts on the central budget, the implementation of the central budget, central taxes, duties, contributions, customs duties or the central conditions for local taxes;

(c) the content of the Acts on the elections of Members of the National Assembly, local government representatives and mayors or Members of the European Parliament;

(d) any obligation arising from international treaties;

(e) person- and organization-related matters falling within the competence of the National Assembly;

(f) the dissolution of the National Assembly;

(g) the dissolution of a representative body;

(h) the declaration of a state of war, state of national crisis and state of emergency; furthermore, on the declaration and extension of a state of preventive defence;

(i) any matter related to participation in military operations;

(j) the granting of amnesty.

Statistically the most commonly used substantive limits are, apart from the positive scope of referendums, the prohibition on constitutional amendments, the fiscal exemption and the prohibition relating to international obligations. ${ }^{17}$

16 See: Zoltán Pozsár-Szentmiklósy, 'Direct democracy in Hungary: from popular sovereignty to popular illusion' (European Constitutional Democracy in Peril: People, Principles, Institutions Conference, Budapest, June 2016) https://www.academia.edu/ 28770995/Direct_democracy_in_Hungary_from_popular_sovereignty_to_popular _illusion, accesse $\bar{d} 1$ April 2020.

17 A thorough analysis was carried out about the decisions of the National Election Commission between January 2014 and December 2017 based on 227 questions by 


\subsection{Positive Scope of Referendum Issues}

Under Hungarian law any matter can be put to a referendum that falls within the functions and powers of the National Assembly and is not prohibited. A valid referendum creates an obligation for the National Assembly to execute the will of the people, thus the legislature needs to have the respective competence. Before the adoption of the new Fundamental Law, the Constitutional Court interpreted this provision widely. Basically, any national issue could be the subject of a referendum, as the powers of the National Assembly were, according to the Constitutional Court, complete and open. ${ }^{18}$ After the review powers were transferred to the Curia, it rather swiftly limited this wide interpretation and departed from the previous practice of the Constitutional Court. ${ }^{19}$ In the Knk.37.807/2012 case the Curia reviewed the decision of the election commission in which it had refused to validate the question 'Do you agree that no football stadium should be built by 31 December 2014 in Felcsút using public funds?' The election commission and the Curia agreed that the question falls within the powers of the executive and thus outside the positive scope of referendums. Interpreting the competence to decide on building a stadium also as a legislative competence would make this positive condition fictitious as all questions could be interpreted as such. According to the Curia this would be in violation of the exceptionality of referendums based on the popular sovereignty clause of the Fundamental Law. ${ }^{20}$ This narrow interpretation of legislative competences was criticized by the legal literature, ${ }^{21}$ as it is not well founded in the principles of separation of powers and hierarchy of norms, while it also creates a possibility for the Government to shield some issues from referendums by simply regulating them.

Neither the Fundamental Law (or previously the Constitution), nor the Referendum Act contains any additional positive condition on the issues that could be put to a referendum. However, the Constitutional Court concluded relatively early on that other restrictions on referendums can be inferred from

János Mécs, ‘Az egyértelmüség követelménye az országos népszavazási kérdések hitelesítése során' (Jogi Tanulmányok, ELTE Állam-és Jogtudományi Kar Állam-és Jogtudományi Doktori Iskola, 2018); similar results in Antalicz (n 8) 185-187.

18 53/2001 (XI. 29.) CC decision and later: 46/2006 (X. 5.) CC decision, 90/2008 (VI. 19.) CC decision.

19 This is also worth noting because the Curia made it clear from the beginning that it would adhere to the previous practice of the Constitutional Court, see: Kvk.O.37.300/2012/2.

20 This interpretation was consistently upheld by the Curia in Knk.VII.37.647/2018/2, Knk.IV.38.258/2018/2, Knk.VII.37.695/2016/3, Knk.IV.37.222/2016.

${ }^{21}$ See László Komáromi, ‘A Kúria határozata a felcsúti labdarúgó-stadionról szóló népszavazási kezdeményezésről’ [2013] 4 JeMa 37. 
the Constitution..$^{22}$ As one consequence, restrictions have started to emerge in the judicial practice based on the 'constitutional functions' of referendums.

One line of argument is based on the importance of the question, which is clearly linked to the positive scope of referendums. ${ }^{23}$ The preamble of the Referendum Act states that 'it is part of the democratic exercise of power that when deciding the most important issues affecting the country, the citizens are involved directly, through referendum.' It is rare that the sole legal base for not validating a question is that the question is not important enough, usually this is a supporting argument. ${ }^{24}$ In the 9/2012. (III. 9.) CC decision, however, the lack of importance argument was the only reason for rejecting an initiative. The initiative proposed that the Constitutional Court should be legally mandated to create a database showing which legal expert works on which decision. The State Election Commission, which was the predecessor of the National Election Commission, refused to authorize the question, stating that it is contrary to the constitutional functions of direct democracy, as it was clearly not a question that belongs to the most important issues affecting the country. The Constitutional Court upheld this decision by a one-line reasoning stating that the plea was unfounded. In the jurisprudence of the Curia, the importance of the question requirement is also traceable, ${ }^{25}$ although its practice is not consistent. In two recent decisions, the Curia reached contradictory conclusions on whether the importance of the question could be a ground for refusing validation. ${ }^{26}$ In both cases the referendum initiatives were about whether the highest state officials shall be entitled to special health care. In the Knk.IV.38.258/2018/2 decision the Curia used the lack of importance of the question as a supporting argument for refusing the initiative. In the Knk. VII.38.256/2018/2 decision, in contrast, it held that even though the preamble of the Referendum Act contains a reference to the importance of referendum questions, the refusal of the validation of an initiative could only be based on the grounds explicitly contained in the Constitution and the Referendum Act.

The other line of argument stems from the principle of exercising rights in good faith in accordance with their purpose. However, this ground for refusal is not connected to the content of the question, but rather to the conduct of the

22 25/1999 (VII. 7.) CC decision, which upheld the practice that constitutional amendments are prohibited, even though the limits on referendums had been reformed in 1997 and the then new rules did not contain such a limitation.

23 See 18/2008 (III.12.) CC decision or Curia decision Kvk.III.37.223/2016/2 about the infamous case of the concurrent Sunday shop closing initiatives (also in: Pállinger (n 6) 21-22).

24 Mostly to support the clarity requirement, see 75/2009 (VII. 10.) CC decision.

25 See Knk.IV.37.484/2013/2.

26 Knk.VII.38.256/2018/2 and Knk.IV.38.258/2018/2. 
initiators. This principle first appeared in the height of the referendum frenzy in 2006-2007. A number of questions were submitted to validation that were deemed frivolous or contained the same issue in different versions of wordings. The Constitutional Court held in the 18/2008. (III.12.) CC decision that the practice of submitting a question and then withdrawing and resubmitting it without the real intention of having a referendum is in violation of this principle. Similarly, in a recent decision the Curia held that submitting the same questions with only minor differences in wording revealed the intent of the organizers to leave it up to the election commission to choose the proper version, which could also be in violation of the principle. ${ }^{27}$

\subsection{Constitutional Amendments as Prohibited Issues}

One of the most important changes to the provisions on referendums in the new Fundamental Law was that the list of prohibited subjects was expanded to include constitutional amendments. This change codified a respective practice of the Constitutional Court. Since 1993 the Constitutional Court had consistently held that an issue cannot be allowed to be submitted to a referendum if it envisages an implied amendment of the Constitution. ${ }^{28}$ The Court differentiated between ordinary legislative and constitutional competences of the parliament and held that amending the Constitution falls within the exclusive competence of the National Assembly. Citizens could not deprive the National Assembly from this exclusive authority, as popular sovereignty is exercised directly only in exceptional circumstances and within the framework of the Constitution. Nevertheless, the 25/1999. (VII. 7.) CC decision of the Constitutional Court also emphasized that this prohibition only applies to citizen-initiated referendums, while the state institutions can decide to ask for a confirmative referendum on constitutional amendments. In contrast, the new Fundamental Law prohibits constitutional amendments for all types of referendums. This prohibition has far-reaching implications: it is virtually impossible to initiate a referendum on any issue related to fundamental rights or state institutional settings.

In case of fundamental rights, the Curia rather consistently applies the same judicial test. It first examines if the question may envisage the restriction of a fundamental right and then analyses the question based on the necessityproportionality test created by the Constitutional Court and now enacted in

${ }_{27}$ Knk.VII.37.959/2017/3; see also Knk.VII.37.520/2017/2 and Knk. VII.37.523/2017/2 and, in a different context, Kvk.III.37.223/2016/2 about the infamous case of the concurrent Sunday shop closing initiatives; see also Pállinger (n 6) 21-22.

$28 \quad 2 / 1993$ (I. 22.) CC decision. 
Article I (3) of the Fundamental Law. According to this test 'a fundamental right may only be restricted to allow the effective use of another fundamental right or to protect a constitutional value, to the extent absolutely necessary, proportionate to the objective pursued and with full respect for the essential content of that fundamental right'. ${ }^{29}$ If the collision between fundamental rights or values can only be lifted through the amendment of the Constitution, the referendum question cannot be authorized. The Curia has applied this test in a series of anti-corruption questions. ${ }^{30}$ In the Knk.IV.37.416/2015 case, the initiators aimed to oblige the family members of politicians and government leaders to publicly declare their assets. The Curia held that this would be a disproportionate restriction of the protection of personal data. First, the Curia stated that in the current regulatory framework both high-level state officials and their family members are obliged to declare their assets, with the one major distinction that only the declarations made by state officials are public information. Making information on private assets public presents a conflict between the protection of personal data encompassed in the respect for private life and the transparency (and accountability) of public life. The Court held that even though the latter fundamental value can necessitate the restriction of private life, the publication of private assets is not a proportionate restriction in case of family members. While high-level state officials voluntarily accept their position, knowing that it entails the obligation to make their private assets transparent, this voluntary element is missing in the case of family members. Thus, they would be obliged to publish private information without their consent or control, which would be a disproportionate restriction of their private sphere.

The National Election Commission applies the same test to deal with questions of fundamental rights - for instance, when questions regarding the reinstatement of the death penalty resurface from time to time. ${ }^{31}$ In these cases, the National Election Commission cites the landmark case of the Constitutional Court on the abolishment of the death penalty, which held that the death penalty not only restricts the right to life and human dignity but amounts to a complete and irreversible elimination of their essential content. ${ }^{32}$ It follows that the reinstatement of the death penalty would require the amendment of

\footnotetext{
29 See for example 64/1991. (XII. 17.) CC decision, 22/2003. (IV. 28.) CC decision.

30 Knk.IV.37.386/2015/3, Knk.IV.37.387/2015/3, Knk.IV.37.388/2015/3, Knk. IV.37.416/2015/2, Knk.IV.37.488/2015/3.

31 See for example Decisions 130/2015, 122/2015, 99/2015, 50/3013 or Decisions 1/1999 (I. 14.), 49/2005 (XII. 15.).

32 23/1990. (X. 31.) CC decision http://www.codices.coe.int/NXT/gateway.dll/ CODICES/precis/eng/eur/hun/hun-1990-s-003 ?fn=document-frameset.htm \$f= templates\$3.0, accessed 1 April 2020.
} 
the constitutional guarantees of the right to life and human dignity and thus falls within the referendum exception. ${ }^{33}$ Interestingly, the State Election Commission used a different argument before 2013 to refuse such questions: it based the refusal on the prohibition of holding referendums on obligations arising from international treaties, as Hungary has ratified the Second Optional Protocol to the International Covenant on Civil and Political Rights, aiming at the abolition of the death penalty. ${ }^{34}$

To my knowledge, the Curia has validated only one question where the claim was based on fundamental rights and values. In the Knk.VII.37.424/2017/2 decision it upheld the validation decision of the National Election Commission regarding a question that aimed at increasing the limitation periods for corruption crimes. A citizen challenged the validation decision and argued that the ratione temporis of the question was not clear, which violated the principles of rule of law and nulla poena sine lege, as the longer limitations could apply for crimes already committed. The Curia argued that the principle of non-retroactivity is part of the criminal legislation, so in case of a successful referendum, the new provisions on the statute of limitations could be adopted and interpreted only in a way to adhere to these principles. This implies that the referendum would not result in amendment of these constitutional values.

Questions on institutional settings are equally rare to reach a vote. In recent years there have been a series of attempts to limit the re-election of the prime minister to the maximum of two government cycles. ${ }^{35}$ Although the Constitution is silent about this question, the Curia held each time that the introduction of such a limit would require the amendment of the Constitution. According to its reasoning, the position of the prime minister is a key element in a parliamentary system, as the parliament has the sovereignty to elect the prime minister who is then accountable to the representative body. Introducing a term limit would encroach on the liberty of parliament to choose a prime minister and change the state structure envisaged by the Constitution and thus cannot be the subject of a referendum. These decisions are particularly interesting as they equate the Constitution being silent about a question with its being implicitly regulated, thus widening the scope of this prohibition. ${ }^{36}$

See for example Decision 99/2015.

4 See for example Decisions 353/2009 or 1/1999 (I. 14.).

35 Knk.IV.37.790/2013/2, Knk.IV.37.394/2017/3, Knk.IV.37.394/2017/3 and Knk. IV.37.567/2018/2.

36 See also Csaba Erdős, 'A Kúria két határozata a miniszterelnöki ciklusok számának maximalizálására irányuló népszavazási kezdeményezésekröl’ [2017] 4 JEMA 41. 


\subsection{Obligations Arising from International Treaties as Prohibited Issues}

Since substantive prohibitions on referendums have existed in the Hungarian system, international obligations have always been among them. However, the wording of this prohibition has changed with the Fundamental Law. Under the old Constitution, the prohibition attached only to valid, ratified international obligations, which meant that it was possible to have referendums about future international obligations or even an international treaty that had already been signed by Hungary but not yet ratified. ${ }^{37}$ The Fundamental Law left out the reference to 'valid' international treaties, so that it is now questionable whether an international treaty not yet in force can be the subject of a referendum. ${ }^{38}$ By contrast, referendums about leaving international organizations to which Hungary is a party (EU, NATO, UN) can never be the subject of a referendum. ${ }^{39}$

The case law shows that the prohibition of holding referendums about international obligations is usually clear when international treaties are affected. ${ }^{40}$ However, placing EU law obligations within this system still poses challenges. While in cases about primary sources of EU law the Curia emphasizes their international legal character, in cases about secondary legal sources their 'special legal status' is highlighted. Regarding a question about prohibiting foreign nationals from acquiring agricultural land, the Curia stated that even though all provisions of EU law have become part of the Hungarian legal system, it shall not be forgotten that the Treaty of Accession is still an international treaty and thus the question was prohibited. ${ }^{41}$

Meanwhile the Curia reached a different conclusion in case of the quota-referendum. After the National Election Commission had authorized the government-initiated question 'Do you want the European Union to be able to mandate the obligatory resettlement of non-Hungarian citizens into Hungary even without the approval of the National Assembly?', the Curia upheld the validation in the Knk.IV.37.222/2016/9 decision. The Curia argued that the

37 The question has arisen in relation to the Constitutional Treaty of the EU and the confirmatory vote initiated on the subject; see 58/2004 (XII. 14.) CC decision.

38 Pállinger (n 6) 11 and László Komáromi, ‘A népszavazásra vonatkozó szabályozás változásai az Alaptörvényben és az új népszavazási törvényben’ [2014] 35 MTA Law Working Papers 6.

39 Kvk.II.37.186/2012/2, Kvk.II.37.185/2012/2, Kvk.II.37184/2012/2 or Knk. IV.37.712/2016/2.

40 See cases about blocking the expansion of the Paks nuclear power plant: Knk. IV.37.358/2015/3, Knk.37.178/2014/3.

$41 \quad$ Knk.IV.37.446/2014/3. 
question was related to the Council Decision (EU) 2015/1601 on establishing provisional measures in the area of international protection for the benefit of Italy and Greece, ${ }^{42}$ which was part of the secondary legal sources of EU law. As such it was part of the special legal order of the EU, which cannot be equated with obligations arising from international treaties. The Fundamental Law regulates the sovereignty transfer to the EU (Article E) and international treaty obligations (Article Q) separately, and according to the Curia only the latter belong to the prohibited issues.

All parties challenging the quota-decision argued that the question did not even belong to the competences of the National Assembly, as the Government was allowed to take part in the EU decision-making procedures and the National Assembly had no influence on EU decisions reached in the Council. The Curia laconically refused these arguments by stating that the legislative competences of the National Assembly are open towards any social relation and can regulate any issue. ${ }^{43}$ In contrast, in a later case about joining the European Public Prosecutor's Office, the Curia emphasized that the decision to participate in the Council Regulation on the establishment of the European Public Prosecutor's Office ${ }^{44}$ was left to the Government as the main actor of the Council and outside the scope of functions of the National Assembly. ${ }^{45}$

\subsection{Fiscal Legislation as a Prohibited Issue}

A large number of initiatives are refused in Hungary because they would affect the content of fiscal legislation. The Constitutional Court laid down the main principles that govern this prohibited subject in its 51/2001 (XI. 29.) CC decision. ${ }^{46}$ The Court emphasized that prohibited issues should be interpreted

42 Council Decision 2015/1601 of 22 September 2015 establishing provisional measures in the area of international protection for the benefit of Italy and Greece [2015] OJ L 248.

${ }^{43}$ Here the decision quotes the Knk.IV.37.807/2012/2. decision, which reached significantly different conclusions about legislative and executive power.

44 Council Regulation 2017/1939 of 12 October 2017 implementing enhanced cooperation on the establishment of the European Public Prosecutor's Office ('the EPPO') [2017] OJ L 283.

45 Knk.VII.37.942/2018/2.

46 Additionally, the 2008 'three-yes' or 'social' referendum was surrounded by debates about this principle, more specifically, about the distinction between the revenue and the expenditure side of the budget and the type of revenues that can be the subject of referendums. See 15/2007 (III. 9.) CC decision, 16/2007 (III. 9.) CC decision, 32/2007 (VI. 6.) CC decision, 33/2007 (VI. 6.) CC decision, 34/2007 (VI. 6.) CC decision, 58/2007 (X. 17.) CC decision, 59/2007 (X. 17.) CC decision, 60/2007 (X. 17.) CC decision and later: Knk.IV.37.339/2015/3. 
narrowly and the fiscal restriction could not be interpreted in a way to cover all legislative acts with fiscal-monetary impact as virtually all issues within the functions of the National Assembly have such an impact. It held that this restriction covers three cases: a referendum cannot oblige the National Assembly to amend the current annual acts on the central budget or acts on the implementation of the central budget, and it cannot aim to precisely determine single fiscal expenditures of future acts on the central budget. This interpretation has been upheld by consequent decisions, although the narrow interpretation of these budgetary acts has widened over the years. In general, it is usually a clear case of a prohibition when the current budget is affected. However, when future revenues or expenditures are in question, the election commission and the courts are not always consistent in determining how close the connection between the question and the budgetary issue must be to warrant refusal of the validation. ${ }^{47}$

\section{FORMAL LEGAL LIMITS ON REFERENDUMS}

Article 9 of the Referendum Act states that 'the question proposed for referendum shall be worded in such manner that it allows a straightforward response, and permits the National Assembly to decide - on the basis of the outcome of the referendum - whether it has the obligation to make a law, and if so, what kind of a law.' Over 70 per cent of the referendum questions are not validated due to violation of this clarity of question requirement. ${ }^{48}$

Based on the landmark 52/2001 (XI. 29.) CC decision a question proposed for a referendum has to fulfil two - sometimes contradictory - conditions: clarity for voters and clarity for legislation. A question has to be clear and straightforward for the voters, without requiring the use of legal or other scientific terms. At the same time, it must be clear for the legislator if and what kind of legislative obligations the question creates. These two requirements often contradict each other, as the more precisely the question is formulated, the easier it is for the legislature to implement the results, but the more difficult it is for the voters to understand it. ${ }^{49}$ A proposed issue can consist of several questions. However, if they contradict each other or their internal connection is not clear or they are not connected substantively to each other, then the clarity

47 See Knk.IV.37.467/2015/2 Decision annulled by 28/2015 (IX. 24.) CC decision; see also László Komáromi, ‘Az Alkotmánybíróság határozata a nőkre vonatkozó kedvezményes nyugdíjba vonulási feltételek férfiakra történő kiterjesztésére irányuló népszavazási kezdeményezésről' [2016] 1-2 JEMA 5.

48 Mécs (n 17) 110-111.

49 See at Curia Knk.VII.37.371/2017/2, Knk.VII.37.336/2017/3, Knk. IV.37.333/2017/5, Knk.VII.37.326/2017/3. 
of question requirement is violated. ${ }^{50}$ As it can be seen, this interpretation of the clarity requirement basically contains a unity of substance requirement as well and implicitly excludes longer legal texts or whole legislative acts as questions.

When reviewing questions, the election commissions and courts tend to look beyond the wording of the question and examine the whole legal environment that the question touches upon, including the legal consequences. An example for this trend is the question of free beer. In the first major influx of referendum questions in 2006-2007, the now still existing Two-tailed Dog Party submitted the question 'Do you agree that the customers of restaurants and pubs should not pay for beer?' The Constitutional Court held in the 26/2007. (IV. 25.) CC decision that the question is neither clear for the legislator nor for the people, because it does not point to a source of revenue that should cover the cost of free beer. The voters could not foresee the consequences of their decision and thus it would be not clear for them what they would vote about. This decision is a landmark case because it opened the door to a very searching review under the criterion of clarity. Another great example of this judicial attitude is a more recent decision of the Curia upholding the refusal of the National Election Commission to authorize the question 'Do you agree that all places of business should be closed on Sunday?', because voters could not foresee the changes such a ban would bring to everyday life. ${ }^{51}$ Involving the foreseeable consequences of a question opens up the analysis to a level that virtually any question can be deemed unclear, as any issue can have multiple legal, economic or social consequences.

This expansive review is coupled with a tendency to overly 'protect' voters from complex issues, regardless of the publicity of the issue. In recent years there has been a tendency to submit referendum questions in reaction to current political events. For example, a number of questions were submitted about the status of the Central European University (CEU) and, even more recently, about an amendment of the Labour Act that started a wave of street protests in the winter of 2018. The initiators of the CEU referendums submitted variously worded proposals that all aimed at abrogating the new conditions of the Act on National Higher Education for foreign higher education institutions which CEU could no longer fulfil. One of these initiatives contained CEU specifically, but the others were worded in a more general manner. None of them were authorized by the National Election Commission, and the Curia upheld the refusal decisions. The one mentioning CEU was refused due to the fact that it would create an unconstitutional discriminatory situation if only CEU was

$50 \quad 52 / 2001$ (XI. 29.) CC decision.

$51 \quad$ Knk.IV.37.174/2015/2. 
exempted, ${ }^{52}$ while the more generally worded proposals were refused based on the requirement of clarity: the questions would require voters to have such a deep understanding of complex legal issues that only experts or directly affected persons could have. ${ }^{53}$ This argument could be true if these questions existed in a vacuum. However, they were submitted at the highpoint of political debate and protests. Similar arguments were raised about the amendment of the Labour Act initiative.$^{54} \mathrm{By}$ contrast, the Curia used a rather lenient approach to clarity in the quota-referendum, ${ }^{55}$ even though the legal challenges against the authorization decision of the National Election Commission all raised different concerns about clarity. The Curia held that the question does not violate the requirement of legislative clarity, because the National Assembly could fulfil its obligation not only by the adoption of a legal act, but also by other regulatory instruments. Furthermore, the term 'resettlement' contained in the referendum question was clear as it meant to voters that non-Hungarian citizens would be moved to Hungary for a longer period. ${ }^{56}$

\section{INSTITUTIONS AND PROCEDURES FOR REVIEWING THE LIMITS OF REFERENDUMS}

\subsection{Institutions Reviewing the Limits of Referendums}

The initial decision about authorizing a referendum is an administrative decision in the Hungarian system. Before 2013 the State Election Commission was in charge of validating referendum questions, now it is the National Election Commission. A common feature of both the former and the current central election commissions is that they include(d) elected as well as delegated members. The idea behind this construction is to create an independent body through the elected members, while at the same time providing for participation and representation of the candidates of elections and the political groups elected to the National Assembly. This, however, creates a fragile balance within the commission that changes from election to election.

The rules about the National Election Commission are laid down by the Act on Electoral Procedure. ${ }^{57}$ The National Election Commission shall have at least

\footnotetext{
52 Knk.IV.37.427/2017/3.

53 Knk.IV.37.425/2017/3 and Knk.IV.37.426/2017/3.

54 In Knk.IV.37.164/2019/3 the Curia hold that without a knowledge of the system of the Labour Act the question is not clear for voters.

55 See: Pállinger (n 6) 24.

56 Knk.IV.37.222/2016/9.

57 Act XXXVI of 2013 on Electoral Procedure https://www.valasztas.hu/documents/ 538536/548702/Act+XXXVI+of+2013+on+Electoral+Procedure.pdf/2e82a257-b592 -4819-923f-eac4a18cfec6, accessed 1 April 2020.
} 
seven elected members, who all have to have university-level law degrees. ${ }^{58}$ Conflict of interests rules guarantee that the elected members are neither high-level state or local government officials, nor members or candidates of political parties. ${ }^{59}$ The members are elected for nine years by the National Assembly with the vote of two-thirds of the members of parliament present. ${ }^{60}$ Even though the elected members have always been elected by parliament, it is a new element of the regulation that the term of their mandate is longer than an election cycle. Prolonging their terms can be seen both as a sign of ensuring their independence and as a way to lock in future election decisions. The number of delegated members depends on the number of political groups in the National Assembly (currently also seven), while before general elections or elections to the European Parliament it depends on the number of nominating organizations putting forward national candidate lists. ${ }^{61}$ The mandate of the delegated members from the parliamentary groups lasts from the inaugural session of the National Assembly until the date of the general elections are set. From then until the inaugural session of the new National Assembly, the nominating organizations delegate the members. For instance, at the last general elections in 2018, in total 23 organizations put forward a national candidate list, which meant that 23 organizations gained the right to delegate a member to accompany the seven elected members during the election campaign.

The work of the National Election Commission is assisted by the National Election Office, which is an autonomous government agency with a president appointed by the President of the Republic on a proposal of the prime minister. ${ }^{62}$

The availability of judicial review (by the Constitutional Court) was first introduced in 1997 as part of the then-new Act on Electoral Procedure. ${ }^{63}$ Initially, review was only provided against decisions related to citizen-initiated referendums. However, the Constitutional Court held in the 64/1997. (XII. 17.) $\mathrm{CC}$ decision that legal certainty as part of the rule of law requires that a preliminary constitutional review shall be available for all types of referendums. When the new Fundamental Law was adopted in 2011, the review powers were transferred to the Curia, which as a regular court was more equipped to deal with the heavy referendum caseload. The Curia is the highest regular court in Hungary, which provides extraordinary remedy in criminal, civil and

\footnotetext{
Art. 14, 17 Act on Electoral Procedure.

Art. 18 Act on Electoral Procedure.

Art. 20 Act on Electoral Procedure.

Art. 27 Act on Electoral Procedure.

62 See at https://www.valasztas.hu/web/national-election-office/national-election -office, accessed 1 April 2020.

63 Act C of 1997 on Electoral Procedure.
} 
administrative law cases as well as ensures the uniformity of the application of law by ordinary courts. The review of referendum decisions belongs to the Administrative Department of the Curia.

Until 2012, a single-level judicial review was available against the decisions of the election commission. However, the transfer of review powers to the Curia opened the door to a further extraordinary remedy procedure to the Constitutional Court. The decision of the Curia to uphold or change the authorization decision is considered to be a regular judicial decision, which means that a constitutional complaint procedure is available. ${ }^{64}$ This remedy procedure is rare, because the Constitutional Court applies a strict admissibility test.

\subsection{Procedures for Reviewing the Limits of Referendums}

All referendum initiatives must be submitted to the National Election Commission, which checks both the formal and substantive admissibility of the question. Article 10 of the Referendum Act empowers the President of the National Election Office to reject an initiative that is obviously contrary to the constitutional purposes of the legal institution of the national referendum or does not comply with some basic formal requirements. ${ }^{65}$ There is no remedy against this decision, but the question can be resubmitted and then it must be put on the agenda of the National Election Commission.

Under Article 11 of the Referendum Act, the National Election Commission decides about the validation of the question within 30 days of its submission, preliminary to signature collection. The Commission meetings are open to the public, so the initiators can participate in the meeting. However, the election commission is free to decide what kind of evidence it uses to support its decision. It may - on request - allow the initiators to present an oral statement, ${ }^{66}$ but it is not obliged to do so. The Commission either certifies or refuses the question as a whole; it does not have a competence to modify the wording of the initiative or to validate parts of it.

Anyone affected by the decision can apply for a remedy at the Curia within 15 days of the publication of the resolution. ${ }^{67}$ According to the consistent practice of the Curia, 'affectedness' must be widely interpreted and can encompass basically anyone. The legal interest in the outcome of the ref-

64 See Art. 233 Election Procedure Act, Art. 24(2) Fundamental Law and Art. 27 Act on the Constitutional Court.

${ }_{65}$ For instance, the organizer has not provided personal information or signatures from 20-30 supporters, the question was not submitted by mail or in person, or the moratorium to submit a question with same content applies.

66 Art. 43 Election Procedure Act.

${ }^{67}$ Based on Art. 1, 29 Referendum Act and Art. 222 Election Procedure Act. 
erendum case exists based on the right to vote in the referendum. In the Knk. IV.37.222/2016/9 decision on the quota-referendum, the Curia stated that affectedness is always determined based on the content of the question, so in the instance of the quota-referendum all Hungarian inhabitants were affected. ${ }^{68}$

The referendum procedure at the Curia is considerably different from other administrative law remedy procedures. The Referendum Act determines a 90-day deadline for reaching a decision (30 days if the election commission resolution was not on the merits of the question). The decision is reached in a non-trial procedure, which means that the three-judge panel decides in chambers based on written submission. A trial or an open hearing cannot be held in referendum procedures, thus parties do not have a right to be heard. The Curia decides the merits of the case by the adoption of a resolution, either upholding or altering the resolution of the National Election Commission. ${ }^{69}$ This is a crucial point with regard to the enforcement of due process guarantees. In other administrative law cases, if the Curia notices that the administrative body or the lower-level court conducted a procedure in serious violation of procedural rules, it annuls the lower-level decision and instructs the administrative body or court to conduct a new procedure that adheres to the due process guarantees. In referendum cases, the Curia does not have cassation powers. Furthermore, the design of its procedure is not equipped to substitute for violations of due process. This means that if the National Election Commission conducts a procedure that is in violation of due process (for instance, it does not decide by majority vote) or if there are other procedural shortcomings (for example regarding affectedness), the Curia has no means to correct the violation. ${ }^{70}$ It can observe in its resolution that procedural rights have been violated, but it cannot offer an effective remedy.

Based on Article 233 of the Election Procedure Act, a constitutional complaint to the Constitutional Court can be submitted against the decision of the Curia. This is an extraordinary remedy procedure, so the Constitutional Court adheres to strict standards when deciding about the admissibility of the case. In the 3195/2014. (VII. 15.) CC decision, the Constitutional Court clarified that the constitutional complaint cannot be admitted if it only contests the interpretation of the prohibited subjects by the Curia. Instead, the applicants have to show that the Curia's decision is significantly affected by a violation of the Fundamental Law or that the case raises constitutional law issues of fundamental importance. ${ }^{71}$ In addition, the applicants only have standing if the judicial

\footnotetext{
See also Knk.IV.37.002/2018/2, Knk.VII.37.427/2017/3.

Art. 30 Referendum Act.

Knk.VII.37.868/2018/2 or Knk.IV.37.222/2016/9.

Art. 29 Act on the Constitutional Court.
} 
decision is contrary to the Fundamental Law because it violates their rights laid down in it. ${ }^{72}$ If admitted, the Constitutional Court decides 'within reasonable time' based on the petition and other written submissions available. ${ }^{73}$

\section{TRENDS AND CONCLUSIONS}

As mentioned earlier, more than 90 per cent of referendum initiatives are rejected by the election commission and the courts. The Hungarian legal system imposes many restrictions on referendums and these restrictions are usually interpreted widely. Thus, the institutional positions and practices of the election commission and the courts also play a crucial role in the rejection rates.

The decision-making practice is strongly influenced by the former decisions of the Constitutional Court. ${ }^{74}$ Today, the Curia also actively shapes the judicial practice of referendums, which the National Election Commission follows. Even though the National Election Commission is a special administrative body whose constantly changing composition of elected and delegated members could politically influence its decisions, the existence of judicial review constrains such trends. It could not even be said that the National Election Commission follows a stricter or a more lenient practice than the courts. ${ }^{75}$ All referendum authorities follow a very restrictive practice.

Both the Constitutional Court and the Curia have expanded the formal and substantive limits, usually as a reaction to an unexpected development in practice. For instance, the influx of 'not serious' questions ${ }^{76}$ in 2007 gave way to analysing legal consequences in clarity review or requiring referendum questions to cover 'important issues' or to be submitted 'in good faith in accordance with their purpose'. However, these additional requirements have been built into the practice and have started to expand themselves. ${ }^{77}$

72 Art. 27 Act on the Constitutional Court; see for instance 3130/2016 (VI. 29.) CC decision or 3117/2019 (V. 17.) CC decision.

73 Based on Art. 57 Act on the Constitutional Court, the Court may order a hearing, but it has never done so in a referendum case.

74 The $31 / 2013$ (X. 2.) CC decision explicitly upheld the previous practice.

75 Since the power of judicial review has been transferred to the Curia, the Curia has reversed a refusal decision of the National Election Commission (and thus authorized the respective referendum question) in only 11 cases out of the 198 cases decided between 2012 and August 2019. In four cases it has reversed an acceptance decision.

76 The free-beer question was followed by questions like 'Do you want to have a mountain on Hortobágy?'

77 For instance, in a recent decision the National Election Commission argued that a referendum question about the term limit of the attorney general was in violation of exercising rights in good faith in accordance with their purpose because of its political 
Additionally, the interpretation of the explicit limitations has also widened over time. For example, the prohibition of holding referendums on constitutional amendments can be now interpreted in a way that also the silence of the Fundamental Law on a specific issue falls under it, while the monetary-fiscal prohibition can cover even very indirectly related questions. ${ }^{78}$ Even though both the Constitutional Court and the Curia have created judicial tests to analyse the applicability of the limits, these tests leave a large margin of discretion to the National Election Commission and to the courts themselves. This leeway shows especially in the inconsistencies of the practice, as for example the strict interpretation of clarity breaks down in the quota-decision. ${ }^{79}$

The judicial review unifies the practice, but also juridifies the referendum process. In general, judicial decision-making adheres only to legal standards of review. As a trend, the Curia even overemphasizes the legal character of review in order to distance itself from the political realities behind the questions and from the possible political attacks. A judicial review is a legal review and should not take account of political reasons, but referendum cases - and especially cases about clarity - should not be decided completely in the abstract, as if they did not exist in a social-political reality.

The heightened scrutiny of legal limits blocks almost all initiatives before citizens could become aware of them and show their support. However, the validation of more questions would not necessarily lead to more referendums, let alone to more successful referendums. The Hungarian referendum practice shows that only political parties with strong support can gather the necessary amount of signatures, and the heightened quorum requirements are almost impossible to reach. Only two of the seven referendums held since 1989 would be valid under the current quorum requirements. ${ }^{80}$ Even the Government could not reach them in the quota-referendum, despite spending more money on the campaign than both sides of the Brexit campaign together. ${ }^{81}$

motivations. The Curia rightly held that neither the National Election Commission nor the Curia itself has the authority to inquire into the political motivations of a question (Knk.VII.37.959/2017/3).

78 28/2015 (IX. 24.) CC decision.

79 See Pozsár-Szentmiklósy (n 16).

80 Voter turnouts in the seven referendums: 1989: 58.03\%, 1990: 14.01\%, 1997: 49.25 \%, 2003: 45.62\%, 2004: 37.49\%, 2008: 50.51\%, 2016: 44.08\%. See https://www .valasztas.hu/orszagos-nepszavazasok, accessed 1 April 2020 and István Kukorelli, Kell-e nekünk népszavazás - Elrendelt népszavazások Magyarországon 1989-2019 (RETÖRKI, Antológia Kiadó, 2019).

${ }^{81}$ See Tamás Lattmann, 'Referendum on the refugee quotas in Hungary - protection of sovereignty or much ado about nothing?' (International Law Reflection \#7, 4 October 2016) http://www.dokumenty-iir.cz/ILR/Reflection_7.pdf, accessed 1 April 2020. 